Cakrawala Dini: Jurnal Pendidikan Anak Usia Dini | p-ISSN 2087-I317 | e-ISSN 2621-8321

Vol. II. No.I Mei 2020 | Hal 30-36

\title{
PENGARUH REGULASI EMOSI TERHADAP PERILAKU PROSOSIAL ANAK USIA DINI
}

\author{
Rizky Drupadi ${ }^{1}$ \\ ${ }^{1}$ Universitas Lampung
}

\begin{abstract}
This study aimed to investigate the influence of perspective taking and emotion regulation on prosocial behavior in early childhood. The quantitative research with expofacto method was employed through survey. The result of the research showed that: (1) perspective taking had a significance influence on the early child's prosocial behavior with $p=0.000$ ( $p<0.05)$, which means that perspective could predict prosocial behavior in early childhood; (2) emotion regulation had a significance effect on early child's prosocial behavior with $p=0.000$ ( $p<0.05$ ), meaning that emotion regulation could predict prosocial behavior in early childhood; (3) perspective taking and emotion regulation had a significance effect on prosocial behavior with $p=0.000(p<0.05)$, which means that both perspective occupying and emotion regulation could predict prosocial behavior in early childhood. Perspective taking and emotion regulation gave $20.8 \%$ effective contribution to prosocial behavior.
\end{abstract}

Keywords: emotion regulation, prosocial, early childhood

\begin{abstract}
Abstrak: Penelitian ini bertujuan untuk mengetahui pengaruh pengambilan perspektif dan regulasi emosi terhadap perilaku prososial pada anak usia dini. Pendekatan penelitian menggunakan penelitian kuantitatif dengan jenis studi expo facto dengan pengambilan data secara survey. Pengumpulan data pada penelitian ini menggunakan kuesioner yang ditunjukkan kepada guru kelas untuk memperoleh data regulasi emosi pada anak, dan perilaku prososial menggunakan wawancara yang ditunjukkan kepada anak. Hasil penelitian menunjukkan bahwa regulasi emosi berpengaruh signifikan terhadap perilaku prososial anak usia dini dengan $\mathrm{p}=0,000 \quad(\mathrm{p}<0,05)$, artinya regulasi emosi dapat memprediksikan perilaku prososial pada anak usia dini; regulasi emosi memberikan sumbangan efektif sebesar $8,5 \%$ terhadap perilaku prososial
\end{abstract}

Kata Kunci: regulasi emosi, prososial, anak usia dini

'Universitas Lampung, Email: rizky.drupadi国kkip.unila.ac.id 


\section{PENDAHULUAN}

Anak usia dini adalah sosok individu yang sedang menjalani suatu proses perkembangan dengan pesat dan fundamental. Anak usia dini berada pada rentang usia 0-6 tahun, periode usia yang menetukan dalam pembentukan karakter dan kepribadian anak (Sujiono, 2009). Pada masa ini anak usia dini mengalami masa keemasan (golden age) dimana semua potensi (agama, moral, fisik, bahasa, kognitif, emosi, sosial, dan seni) yang dimiliki anak mengalami pertumbuhan dan perkembangan yang sangat pesat. Hal ini dikarenakan perkembangan otak pada anak usia mengalami percepatan hingga $80 \%$ dari keseluruhan otak orang dewasa (Suyadi, 2010). Oleh karena itu untuk menciptakan generasi yang berkualitas, pendidikan harus dilakukan sejak dini, yaitu melalui Pendidikan anak usia dini (PAUD).

Salah satu aspek yang penting dalam lingkup perkembangan anak usia dini adalah sosial-emosional. Aspek perilaku prososial merupakan bagian dasar tingkat pencapain perkembangan sosial emosional dalam pembelajaran anak usia dini khususnya Taman Kanakkanak. Eisenberg dan Mussen (1989) menjelaskan bahwa perilaku prososial adalah tindakan sukarela yang dimaksudkan untuk membatu atau menguntungkan orang lain atau sekelompok orang. Perilaku prososial ini meliputi berbagi sesuatu dengan orang lain, menunjukkan kesediaan untuk bekerja sama, membantu dan menghibur seseorang dalam kesusahan.

Perilaku prososial ini memainkan peranan penting dalam kehidupan sosial. Apabila manusia tidak mampu menunjukkan perilaku prososial seperti membantu, berbagi, dan bekerjasama, akan sulit untuk hidup dalam kelompok sosial. Pada dasarnya, manusia merupakan makhluk sosial, di mana manusia membutuhkan bantuan orang lain dalam kehidupannya.
Hal seperti ini tidak hanya dialami dan dirasakan oleh orang dewasa saja melainkan pada anak-anak juga. Anak bukanlah miniatur orang dewasa, anak merupakan pribadi unik yang harus diakui eksistensinya. Anak merupakan bagian dari keluarga, sebuah kelompok kerabat, lingkungan bertentangga, masyarakat, negara, dan dunia. Untuk menjadi anggota dari lingkungan kehidupannya sejak awal anak perlu mempelajari aturan-aturan dalam hidup bermasyarakat sedari awal terutama perilaku prososial.

Pengembangan perilaku prososial merupakan salah satu jenis kompetensi sosial yang penting dimiliki oleh anak usia dini. Perkembangan pada masa awal ini akan menjadi penentu perkembangan selanjutnya. Marion (2015) mengatakan bahwa perilaku prososial ini dimaksudkan untuk memenuhi kebutuhan seseorang, baik fisik, psikologis/emosional, atau keduanya. Sejalan Eisenberg (Santrock, 2007) yang menyimpulkan bahwa perilaku prososial bersifat stabil mulai dari masa kanakkanak awal hingga masa dewasa awal. Oleh karena itu, perilaku prososial harus ditanamkan sejak dini kepada anak dalam pembelajaran yang diselenggarakan di PAUD sebagai persiapan memasuki jenjang lebih tinggi yaitu sekolah dasar.

Fakta di lapangan perilaku prososial meunjukkan hal yang berbeda. Agresif verbal masih sering terjadi, ditunjukkan dengan masih adanya anak yang berkata buruk terhadap teman, merebut barang milik teman, memukul teman dan lain sebagainya. Selain itu agresi secara psikologis seperti tidak mengizinkan teman ikut bermain, tidak memperbolehkan teman duduk didekatnya pun sering kali terjadi. Hal ini cukup memprihatikan, mengingat hal ini terjadi pada anak usia dini.

Peranan media elektronik dan media cetak juga memberikan pengaruh yang besar terhadap kecenderungan sosial. Friedrich dan Stein (1973) 
menemukan bahwa perilaku agresif dan perilaku prososial dari program televisi berpengaruh terhadap perilaku anak-anak usia dini. Jika yang dilihat adalah konten negatif, maka akan berpengaruh terhadap perilaku negatif maupun sebaliknya. Sejalan dengan penelitian Dumova (2006) bahwa televisi memiliki efek positif pada anak-anak dengan mengeksplorasi tema prososial dan mengembangkan konten yang berorientasi pada masyarakat. Permasalahannya di Indonesia tayangan televisi cenderung menampilkan kontenkonten yang kurang edukatif, hampir setiap hari di dalam tayangan televisi dan media cetak ditampilkan bentuk-bentuk perilaku antisosial seperti kekerasan. Tayangan seperti kekerasan tersebut secara bebas dapat dilihat oleh anak-anak sehingga mereka dengan mudah mencontohnya.

Dari hasil wawancara kepada beberapa guru kelas TK diperoleh data bahwa perilaku prososial pada anak sudah mulai tampak, akan tetapi ada juga yang belum tampak. Perilaku prososial yang tampak terlihat pada beberapa anak yaitu adanya anak yang menghampiri temannya yang menangis, kemudian beberapa anak yang berbagi bekal dengan temannya maupun bermain dengan teman-temanya. Sebaliknya ada juga perilaku anak seperti berkelahi karena berebut mainan, ketika melihat temannya menangis anak-anak yang lain cenderung tidak peduli, sampai ada juga anak yang tidak mau bermain dengan temannya karena tidak begitu dekat.

$$
\text { Perilaku prososial akan }
$$

berpengaruh terhadap perkembangan sosialisasi anak dengan teman sebaya. Battistich (2003), menunjukkan bahwa perilaku prososial berpengaruh dengan penyesuaian sosial anak ketika di sekolah. Anak yang mampu bersosialisasi secara umum akan mudah menerima reaksi yang positif dari teman sebaya ketika menunjukkan tindakan prososial (Eisenberg \& Mussen, 1989).
Berlanjut pada observasi di Taman Kanak-kanak, kurang tampaknya perilaku prososial terlihat pada perilaku anak yang suka mengganggu temannya yang sedang belajar, suka memukul, tidak mau berbagi bekal, mengejek teman yang akhirnya berujung berkelahi, tidak mau meminjamkan mainannya, mengejek temannya yang terjatuh dengan kata "cengeng" daripada menolongnya dan sebagainya. Perilaku ini sering mengganggu jalannya proses pembelajaran di kelas. Lebih lanjut, apabila perilaku ini berjalan sepanjang waktu maka akan meningkatkan gangguan psikologis anak menuju agresi antar sesama anak. Menurut Ormord dan Devitt (2014), agresi adalah tindakan sengaja diambil untuk menyakiti orang lain baik secara fisik maupun psikologis. Anak yang agresif cenderung memiliki masalah penanganan emosi dan memahami hubungan sosial. Hal ini adalah indikator kuat untuk kesehatan mental yang rendah apabila mencapai usia dewasa nantinya

Salah satu aspek lain yang mempengaruhi dalam mencapai perilaku prososial adalah regulasi emosi. Regulasi emosi berhubungan dengan empati dan perilaku prososial (Lockwood, Cardoso, \& Viding, 2014). Thompson, Meyer, dan Jochem (2008) menyatakan bahwa regulasi emosi terdiri dari proses internal dan eksternal yang bertanggung jawab untuk memantau, mengevaluasi, dan memodifikasi reaksi emosional (terutama intensitas dan waktu mereka) untuk mencapai tujuan seseorang.

Anak-anak umumnya mengalami kesulitan dalam pengaturan emosi mereka. Kemampuan anak-anak dalam menyalurkan emosi mereka sangat beragam. Emosi dapat menyebabkan perubahan perilaku, mempengaruhi ketepatan dalam pengambilan keputusan, mempengaruhi daya ingat terhadap suatu peristiwa penting sekaligus dapat memfasilitasi interaksi sosial (Gross, 2014). Penelitian Ensor, Spencer, dan 
Hughes (2011) menghasilkan kesimpulan bahwa untuk berperilaku prososial diperlukan kemampuan memahami emosi orang lain. Sebagai gambaran, seringkali anak-anak menangis maupun marah tanpa bisa dikontrol maupun ketakutan tanpa ada penyebab yang pasti. Eisenberg, Fabes, Jones, Smith, Guthrie, Poulin, Friedman (1999) mengatakan bahwa perbedaan individu dalam regulasi emosi akan berhubungan dengan perilaku prososial dan bahwa orang-orang dengan keterampilan regulasi emosi yang buruk akan menampilkan perilaku kurang membantu. Jadi setiap orang dapat menunjukkan tanggapan empatik yang berbeda-beda karena berbagai kemampuan regulasi emosi.

Kemampuan regulasi emosi pada anak bergantung pada keadaan lingkungan keluarga anak. Orangtua merupakan pihak yang dapat membantu anak-anak mengatur emosi mereka (Thomson dalam Santrock, 2007). Dalam penelitian Morris, Silk, Steinberg, Myers, dan Robinson (2007) dijelaskan bahwa orangtua berperan aktif dalam menumbuhkan kemampuan regulasi emosi anaknya

Berdasarkan latar belakang yang telah disampaikan, peneliti akan mengkaji seberapa besar pengaruh regulasi emosi terhadap perilaku prososial anak usia dini. Secara terperinci, permasalahan penelitian ini adalah: apakah terdapat pengaruh antara regulasi emosi dengan perilaku prososial?

Tujuan penelitian ini adalah untuk mengetahui pengaruh regulasi emosi terhadap perilaku prososial anak usia dini. Manfaat yang diperoleh dari penelitian ini adalah secara teoritis memberikan sumbangan data untuk pengembangan teori terkait dengan perilaku prososial anak usia dini

\section{METODE}

Pendekatan penelitian menggunakan metode penelitian kuantitatif dengan jenis studi ex post facto dengan pengambilan data secara survey. Populasi dalam penelitian ini adalah TK di Kecamatan Seyegan Sleman yang berjumlah 1017 anak. Sampel yang digunakan sejumlah 300 anak. Pengambilan sampel menggunakan teknik stratified proportional random sampling. Pengumpulan data menggunakan kuesioner yang ditunjukkan kepada guru kelas untuk memperoleh data regulasi emosi pada anak, dan perilaku prososial digunakan wawancara yang ditunjukkan kepada anak.

Validitas instrumen dengan menggunakan validitas isi (content validity). Uji reliabilitas dengan menggunakan rumus alpha cronbach diperoleh reliabilitas Skala Regulasi Emosi Cronbach's Alpha 0,919 dari 24 aitem soal, dan Skala Perilaku Prososial Cronbach's Alpha 0,865 dari 22 aitem. Teknik analisis data yang digunakan dalam penelitian adalah analisis regresi linier

\section{HASIL PENELITIAN DAN PEMBAHASAN}

Hasil penelitian menunjukan dari data yang dianalisis berjumlah 300 sampel dan diperoleh hasil signifikansi 0,000 $(p<0,05)$. Hal ini bermakna bahwa terdapat pengaruh positif regulasi emosi terhadap perilaku prososial pada anak. Hasil analisis regresi dapat dilihat pada Tabel 1

Tabel 1. Analisis Regresi

\begin{tabular}{l|r|r|r|r|c}
\hline & \multicolumn{2}{|c|}{$\begin{array}{c}\text { Unstandardized } \\
\text { Coefficients }\end{array}$} & $\begin{array}{c}\text { Standa } \\
\text { rdized } \\
\text { Coeffi } \\
\text { cients }\end{array}$ & & \\
\cline { 2 - 4 } & $\mathrm{B}$ & $\begin{array}{c}\text { Std. } \\
\text { Error }\end{array}$ & Beta & $\mathrm{t}$ & Sig. \\
\hline Model & 3.353 & 1.821 & & 1.842 & .067 \\
$\begin{array}{l}\text { (Constant) } \\
\text { Regulasi_ } \\
\text { Emosi }\end{array}$ & .179 & .034 & .291 & 5.259 & .000 \\
\hline
\end{tabular}


Berdasarkan Tabel 1 diperoleh persamaan regresi $\mathrm{Y}=3,353+0,179 \mathrm{X}$. Berdasarkan persamaan tersebut jika nilai $\mathrm{X}$ telah diketahui maka nilai $\mathrm{Y}$ dapat diketahui dengan mengalikan nilai $X$ dengan nilai koefisien $(0,179)$ yang kemudian dijumlahkan dengan nilai konstanta (3,353). Artinya semakin bertambahnya nilai $X$, semakin bertambah pula nilai $\mathrm{Y}$, sesuai dengan arah koefisien regresinya maka koefisien regresi bernilai positif. Dengan demikian, dapat disimpulkan bahwa semakin bertambahnya nilai dari regulasi emosi semakin meningkat pula nilai dari perilaku prososial anak. Sebaliknya jika nilai dari regulasi emosi menurun maka nilai dari perilaku prososial anak akan menurun, maka persamaan tersebut dapat digunakan untuk memprediksi.

Besarnya sumbangan efektif dan relatif pengambilan perspektif dan regulasi.

Tabel 2. Sumbangan efektif

\begin{tabular}{c|r|r|r}
\hline $\mathrm{R}$ & $\begin{array}{c}\mathrm{R} \\
\text { Square }\end{array}$ & $\begin{array}{c}\text { Adjusted } \\
\text { R Square }\end{array}$ & $\begin{array}{c}\text { Std. Error } \\
\text { of the } \\
\text { Estimate }\end{array}$ \\
\hline $.291^{\mathrm{a}}$ & .085 & .082 & 3.21193 \\
\hline
\end{tabular}

Dapat diketahui pada tabel bahwa sumbangan efektif (R Square ) regulasi emosi sebesar 0,085 atau $(8,5 \%)$ terhadap perilaku prososial anak usia dini. Sedangkan 91,5 \% perilaku prososial anak usia dini dipengaruhi oleh faktor lain.

Berdasarkan hasil analisis data pada penelitian dan pengujian hipotesis dapat disimpukan bahwa regulasi emosi memberikan dampak positif terhadap perilaku prososial anak. Regulasi emosi dapat memprediksikan perilaku prososial pada anak usia dini. Penelitian Lockwood, Cardoso, dan Viding (2014) menyatakan bahwa perkembangan regulasi emosi berhubungan dengan empati dan perilaku prososial anak. Individu yang dapat meregulasi emosinya dengan baik, menunjukkan tingkat kompetensi sosial yang tinggi dan perilaku sosial yang positif (Eisenberg \&
Fabes, 1992; Tanyel, 2009). Schatz, Smith, Borkowski, Whitman, dan Keogh (2008) menjelaskan bahwa anak-anak dengan kemampuan regulasi emosi lemah, cenderung menampilkan perilaku pemberontak atau agresif terhadap orang lain dibandingkan dengan anak yang telah memperoleh keterampilan emosional.

Ada beberapa faktor-faktor lain yang mempengaruhi regulasi emosi anak. Eisenberg (Santrock, 2007) menyebutkan bahwa faktor-faktor yang mempengaruhi regulasi emosi anak adalah orangtua, strategi kognitif, kemampuan mengontrol rangsangan emosi, usia, maupun strategi coping stres. Kalpidou, Power, Cherry, dan Gotfried (2004) yang menerangkan bahwa emosi regulasi anak akan menjadi lebih baik seiring dengan bertambahnya usia anak.

Kemampuan regulasi emosi pada anak harus distimulisasikan sejak dini agar anak dapat memunculkan perilaku yang sesuai dengan harapan sosial. Tanyel (2009) menjelaskan strategi dalam pengembangan regulasi emosi untuk orang tua maupun guru dapat dilakukan dengan cara: luangkan waktu dengan anak-anak beberapa kali sehari dan beradaptasi dengan suasana hati mereka, tunjukkan ekspresi emosional dan peraturannya dengan membaca bukubuku yang berisi kosakata dan situasi emosional, ketika anak mengalami kesulitan dalam mengekspresikan perasaan mereka cobalah untuk mengklarifikasi atau menjelaskan maksud mereka, tunjukkan kepada anakanak bagaimana mendapatkan kembali stabilitas emosional dengan menawarkan kedekatan dan keamanan, membaca komunikasi anak-anak melalui ekspresi wajah dan bahasa tubuh mereka dan kemudian beri label perasaannya, amati dengan cermati (tanggapi perbedaan individu yang mlibatkan anak-anak secara lebih aktif dalam pengalaman dan membicarakannya melalui pengalaman tersebut), tetapkan lingkungan yang dapat 
diprediksi untuk menanggapi atribut biologis dan tempramental anak, tentukan, patuhi, dan hormati batasan yang ditetapkan untuk anak-anak, kenali bahwa kebutuhan anak itu penting, tunjukkan empati dan peduli untuk membantu anak mengembangkan strategi self-calming, dan ikuti jejak anak-anak dalam permainan mereka dengan mengagumi inisiatif mereka.

\section{KESIMPULAN}

Berdasarkan hasil penelitian dan pembahasan, maka dapat disimpulkan bahwa Regulasi emosi berpengaruh positif terhadap perilaku prososial pada anak usia dini. Artinya, regulasi emosi dapat memprediksikan perilaku prososial pada anak usia dini. Regulasi emosi memberikan sumbangan efektif regulasi emosi sebesar 8,5\% terhadap perilaku prososial

Untuk mengembangkan perilaku prososial secara bersama-sama dapat dilakukan dengan meningkatkan regulasi emosi anak. Hal ini dikarenakan, semakin meningkatnya regulasi emosi semakin meningkatkan pula perilaku prososial pada anak. Oleh karena itu, untuk anak usia 4-6 tahun yang perkembangan perilaku prososial belum maksimal, hasil penelitian ini dapat digunakan sebagai acuan dalam meningkatkan perilaku prososial pada anak usia 4-6 tahun.

\section{DAFTAR PUSTAKA}

Battistich, V. (2003). Effects of a schoolbased program that enhance prosocial development on children's peer relations and social adjustment. Journal of Research in Character Education, 1 (1), 1-16

Dumova, T. (2006). Prosocial learning. International Journal of Learning, 12 (9), 184-194

Eisenberg, N. \& Mussen, P.H. (1989). The Roots of prosocial behavior in children. Inggris: Cambridge University Press
Eisenberg, N., \& Fabes, R.A. (1992). Emotion, regulation, and the development of social competence. In M. S. Clark (Ed.), Review of personality and social psychology. Emotion and Social Behavior (Vol. 14, pp. 119-150). Newbury Park, CA: Sage

Ensor, R., Spencer, D., \& Hughes, C.. (2011). "You Feel Sad?" Emotion understanding mediates effects of verbal ability and mother-child mutuality on prosocial behaviors: findings from 2 years to 4 years. Journal Social Development, (20) 1 , 93-110

Fabes, R. A., Eisenberg, N., Jones, S., Smith, M., Guthrie, I., Poulin, R., Friedman, J. (1999). Regulation, emotionality, and preschoolers' socially competent peer interactions. Journal Child Development. 70(2), 432-442

Friedrich, L. K., \& Stein, A. H. (1973). Aggressive and prosocial television programs and the natural behavior or preschool children. Monographs of the Society for Research in Child Development, 38 (151), 1-63

Gross, J.J. (2014). Handbook of emotion regulation. New York: The Guilford Press

Kalpidou, M.D., Power, T.G., Cherry K.E. \& Gotfried N.W.(2004). Regulating of emotion dan behavior among 3 and 5 years old. The Journal of General Psychology,131(2), 159

Lockwood, P.L., Cardoso,A.S., Viding, E. (2014). Emotion regulation moderates the association between empathy and prosocial behavior. Journal Division of Psychology and Language Sciences, 9 (5), 1

Marion, M. (2015). Guidance of young children. Amerika: Pearson

Morris, A. S., Silk, J. S., Steinberg, L., Myers, S. S., \& Robinson, L. R. (2007). The role of the family context in the development of 
emotion regulation. Journal Social Development, 16(2), 361-388

Santrock, J.W. (2007). Perkembangan anak (edisi ketujuh). Jakarta: Erlangga

Schatz, J.N., L.E. Smith, J.G. Borkowski, T.L. Whitman, and D.A. Keogh. (2008). Maltreatment risk, selfregulation, and maladjustment in atrisk children. Child Abuse and Neglect, 32, 972-982

Sujiono, Y. N. (2009). Konsep Dasar PAUD. Jakarta: Indeks.

Suyadi. (2010). Psikologi Belajar Pendidikan Anak Usia Dini. Yogyakarta: Pustaka Insan Madani

Tanyel, N.E. (2009). Emotional regulation: developing toddlers' social competence. Journal Dimensions of Early Childhood, 37 (2) 10-14

Thompson, R. A., Meyer, S. \& Jochem, R. (2008). Emotion regulation. USA: Elsevier Inc 